\begin{tabular}{|l|c|c|c|c|c|}
\hline J. Tek. Ling & Vol. 13 & No. 1 & Hal. $75-84$ & Jakarta, Januari 2013 & ISSN 1441-318X \\
\hline
\end{tabular}

\title{
PENGELOLAAN SAMPAH BERBASIS MASYARAKAT DI RAWASARI, KELURAHAN CEMPAKA PUTIH TIMUR, JAKARTA PUSAT
}

\author{
Sri Wahyono, Firman L. Sahwan dan Feddy Suryanto \\ Peneliti di Pusat Teknologi Lingkungan \\ Badan Pengkajian dan Penerapan Teknologi
}

\begin{abstract}
Abstrak
Pengelolaan sampah berbasis masyarakat (PSBM) adalah sistem penanganan sampah yang direncanakan, disusun, dioperasikan, dikelola dan dimiliki oleh masyarakat. Peran PSBM sangat penting dalam ikut membantu mengurangi permasalahan sampah kota, sehingga konsep tersebut banyak dilakukan di berbagai tempat, termasuk di Rawasari. Penelitian ini dilakukan untuk mengetahui perkembangan kegiatan PSBM di Rawasari, yang secara khusus bertujuan: (i) monitoring dan evaluasi, (ii) pembinaan dan pendampingan, (iii) sosialisasi dan publikasi. Hasil penelitian menunjukkan bahwa kegiatan PSBM di Rawasari berjalan dengan baik, berkat adanya pembinaan yang baik dan berkesinambungan. Hal ini tergambar dari peningkatan jumlah keluarga yang berpartisipasi dalam kegiatan pengomposan dan daur ulang sampah anorganik. Hasil tersebut juga tidak terlepas dari peran kader lingkungan yang ada serta kerjasama yang baik antar stakeholders, baik yang berasal dari pemerintah setempat, instansi kebersihan, lembaga penelitian, LSM, lembaga asing, dan warga setempat. Adanya kegiatan sosialisasi keberhasilan PSBM di RW 01 dan RW 02 melalui kegiatan pencanangan gerakan PSBM oleh Gubernur DKI Jakarta, ikut mendorong keberhasilan PSBM di Rawasari. Pemerintah DKI Jakarta menyadari bahwa peran serta masyarakat, sangat efektif dalam menekan jumlah timbulan sampah. Untuk itu, kegiatan PSBM telah dijadikan sebagai salah satu program utama pengelolaan sampah.
\end{abstract}

kata kunci: pengelolaan sampah, kader lingkungan, daur ulang, pengomposan

\begin{abstract}
Community-based solid waste management (CBSWM) is the solid waste management that are planned, developed, operated, managed and owned by the local community. CBSWM is very important role to reduce the problem of municipal solid waste. This concept is widely applied in various places, including in Rawasari, Central Jakarta. The study was conducted to determine the progress of the CBSWM in Rawasari, which specifically aims to: (i) monitoring and evaluation, (ii) coaching and mentoring, (iii) socializing and publication. The results showed that the activity of CBSWM in Rawasari is going well. This is illustrated by the increasing number of families who participate in composting and recycling of anorganic waste. These good results are affected by the roles of environmental cadres as well as good cooperation between stakeholders, such as local governments, research institutions, NGOs, international agencies, and local residents. The Jakarta administration realizes that the roles of the community are very effective in reducing the amount of waste generation. So that, activities of CBSWM becomes one of the major program in waste management.
\end{abstract}

kay words: Community-based solid waste management, environmental cadres, recycling, composting. 


\section{PENDAHULUAN}

\subsection{Latar Belakang}

Pengelolaan sampah berbasis masyarakat (PSBM) adalah suatu pendekatan pengelolaan sampah yang didasarkan pada kebutuhan dan permintaan masyarakat, direncanakan, dilaksanakan (jika memungkinkan), dikendalikan dan dievaluasi bersama masyarakat ${ }^{1}$. Dikatakan berbasis masyarakat jika: (i) keputusan ditangan masyarakat secara keseluruhan; (ii) tanggung jawab operasi dan pemeliharaannya di tangan masyarakat sesuai dengan kesepakatan. Kalau disederhanakan, PSBM adalah sistem penanganan sampah yang direncanakan, disusun, dioperasikan, dikelola dan dimiliki oleh masyarakat ${ }^{2}$. Dalam pengertian tersebut, pemeran utama dalam pengelolaan sampah adalah masyarakat. Pemerintah dan lembaga lainnya sebagai motivator dan fasilitator.

Andil dari peran serta masyarakat yang begitu nyata dan penting di dalam pengelolaan sampah kota, telah menarik perhatian para stakeholders persampahan, sehingga keterlibatan peran serta masyarakat tersebut telah berkembang menjadi suatu konsep baru dalam pengelolaan sampah dan dikenal dengan istilah PSBM. Ada juga yang menyebut dengan sistem pengolahan sampah berbasis masyarakat ${ }^{3)}$.

Perkembangan PSBM di Rawasari, erat kaitannya dengan keberadaan tempat pengolahan sampah terpadu (TPST) Rawasari yang dibangun oleh Dinas Kebersihan DKI Jakarta tahun 2000. Tujuan awal pembangunan TPST tersebut adalah sebagai penyediaan sarana pengelolaan sampah skala kawasan di DKI Jakarta. Pengelolaan TPST Rawasari dilaksanakan secara bersama antara Pusat Teknologi Lingkungan BPPT sebagai lembaga penelitian dan Dinas Kebersihan DKI Jakarta sebagai pengelola persampahan4), yang tertuang dalam suatu perjanjian kerjasama.
Pada tahun 2005, BPPT mengembangkan TPST Rawasari dengan memperluas bangunan pengomposan dan meningkatkan kegiatan operasionalnya. Selanjutnya pada tahun 2007, dipasang mesin-mesin daur ulang sampah sehingga sarana pendukung TPST Rawasari menjadi semakin lengkap. Pada tahun 2007 itulah kegiatan TPST Rawasari diintegrasikan dengan kegiatan PSBM yang dilakukan oleh RW 01 dan RW 02 Kelurahan Cempaka Putih Timur, Jakarta Pusat, yang merupakan lokasi TPST Rawasari berada. Konsep tersebut akhirnya dikenal dengan Pengelolaan Sampah Terpadu Berbasis Masyarakat di Rawasari (Gambar 1).

Implementasi kegiatan pengembangan dan dukungan terhadap pengelolaan sampah terpadu berbasis masyarakat di Rawasari atau di Kelurahan Cempaka Putih Timur, dimulai setelah diadakan Pelatihan Daur Ulang dan Pengomposan Sampah Rumah Tangga yang dilaksanakan pada tanggal 7 Oktober 2007, dan berhasil mendidik 31 kader lingkungan yang berasal dari RW 01 dan 02 Kelurahan Cempaka Putih Timur.

Untuk melihat aktivitas para kader lingkungan dalam melakukan pengolahan sampah maka dilakukanlah monitoring secara reguler. Pada saat monitoring dilakukan pula pendampingan dan pembinaan kepada para kader lingkungan sehingga apabila menemui kesulitankesulitan teknis dalam melakukan aktivitasnya dapat segera diselesaikan.

Selain itu, kepedulian warga terhadap pengelolaan sampah tetap dipelihara, dan ditumbuhkan rasa bangga akan keberhasilannya antara lain dengan acara pencanangan gerakan 3R oleh Gubernur DKI Jakarta di tempat mereka bermukim.

Untuk mengetahui perkembangan PSBM di Rawasari yang dapat digunakan sebagai acuan dan perbandingan dengan PSBM di lokasi lain, maka dilakukanlah penelitian ini. 


\section{Konsep Pengelolaan Sampah Terpadu Berbasis Masyarakat Di TPST Rawasari}

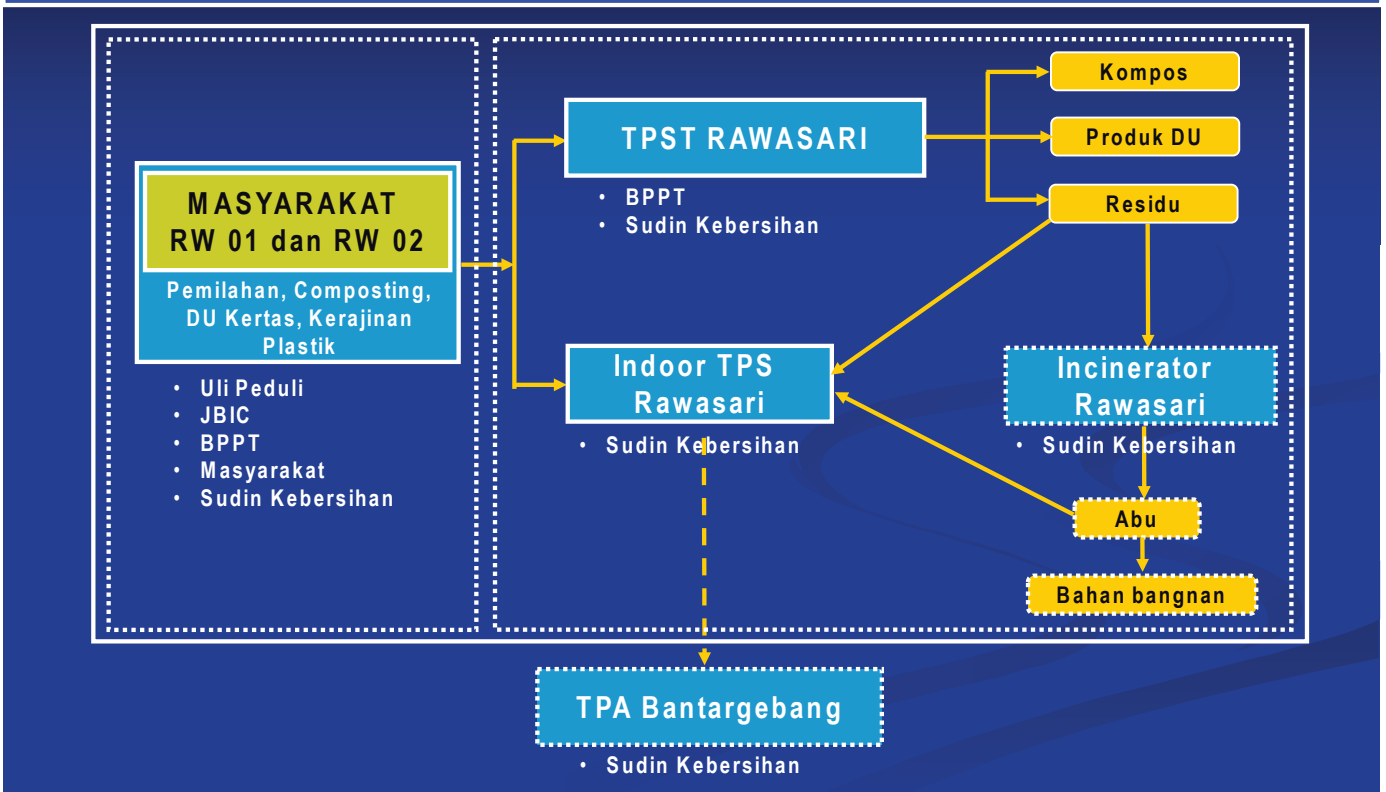

\subsection{Tujuan}

Secara lebih spesifik, penelitian ini dilakukan dengan tujuan:

1. Melakukan monitoring dan evaluasi kegiatan PSBM di Rawasari, terutama kegiatan pengomposan dan daur ulang sampah rumah tangga.

2. Melakukan pembinaan dan pendampingan para kader lingkungan dalam kegiatan pengelolaan sampahnya.

3. Melakukan sosialisasi dan publikasi PSBM di Rawasari ke masyarakat lainnya.

\section{METODOLOGI PENELITIAN}

\subsection{Tempat dan Waktu Penelitian}

Penelitian ini dilakukan di Rawasari (RW 01 dan RW 02) Kelurahan Cempaka Putih Timur. Adapun waktu penelitian dilakukan pada tahun 2007 sampai tahun 2008

\subsection{Cara Penelitian}

Penelitian kegiatan PSBM di Rawasari dengan penekanan pada kegiatan pengomposan dan daur ulang sampah rumah tangga dilakukan dengan cara:

1. Interview secara langsung dengan para kader lingkungan di RW 01 dan RW 02.

2. Penyebaran kuesioner kepada warga di RW 01 dan RW 02

3. Kunjungan monitoring secara reguler 3-4 minggu sekali ke para kader lingkungan

\section{HASIL DAN PEMBAHASAN}

\subsection{Profil RW 01 dan RW 02 Kelurahan Cempaka Putih Timur}

Wilayah lokasi penelitian secara umum meliputi 2 RW yaitu RW 01 dan RW 02 Kelurahan Cempaka Putih Timur. Kedua RW tersebut merupakan daerah permukiman dengan jumlah penduduk sekitar 5.060 jiwa, yang merupakan tipikal untuk DKI Jakarta 
dengan dominansi penduduk kalangan menengah ke bawah.

Tabel 1. Jumlah Penduduk RW 01 dan RW 02

\begin{tabular}{|l|l|c|c|}
\hline \multicolumn{1}{|c|}{ No } & \multicolumn{1}{|c|}{ RW } & $\begin{array}{c}\text { Jumlah } \\
\text { KK }\end{array}$ & $\begin{array}{c}\text { Jumlah } \\
\text { Penduduk }\end{array}$ \\
\hline 1. & RW 01 & 339 & 1356 \\
\hline 2. & RW 02 & 926 & 3704 \\
\hline & Total & 1265 & 5060 \\
\hline
\end{tabular}

Kalau diasumsikan rata-rata timbulan sampah sebesar 2,9 liter per orang per hari ${ }^{5)}$, maka dengan jumlah penduduk 5.060 jiwa, diperkirakan jumlah timbulan sampah perharinya sekitar $15 \mathrm{~m}^{3}$. Setiap 2-3 hari sekali sampah dikumpulkan dengan gerobak dan diangkut ke kompleks TPST Rawasari. Di RW 01 terdapat petugas penarik gerobak 2 orang dengan jumlah gerobak 3 buah, sedangkan RW 02 terdapat 4 orang dengan 7 gerobak.

Sampah dari kedua RW tersebut didominasi oleh sampah organik, 65,55\%. Sedangkan sampah lainnya adalah sampah anorganik yang didominasi oleh sampah kertas $(10,57 \%)$ dan plastik $(13,25 \%)^{5}$. Sebagai perbandingan, rata-rata komposisi sampah di DKI Jakarta sebesar: 55,37\% sampah organik, $24,57 \%$ sampah kertas dan $13,25 \%$ sampah plastik ${ }^{6}$. Sedangkan secara nasional, dominansi sampah organik sebesar $62 \%{ }^{7)}$.

Kegiatan PSBM di RW 01 dan RW 02, sangat berkaitan dengan kader lingkungan yang terbentuk. Kegiatan yang dilakukan oleh JBIC, telah melahirkan kader lingkungan sebanyak 42 orang yang terdiri atas kader yang bermukim di RW 01 dan RW 02 (berjumlah 31 kader) dan yang bermukim di luar kedua RW tersebut (11 kader). Jumlah kader lingkungan yang bermukim di RW 01 berjumlah 22 orang sedangkan di RW 02 berjumlah 9 orang. Tujuh kader di antaranya, merangkap sebagai kader Yayasan Uli Peduli. Sedangkan kader lingkungan JBIC yang tidak bermukim di kedua RW tersebut terdiri atas tukang gerobak (4 kader), anggota Yayasan Dana Mitra Lingkungan (1 kader), Indonesia Waste Forum (2 kader), anggota Yayasan Uli Peduli (3 kader), dan staff Dinas Kebersihan (1 kader).

Tabel 2. Komposisi Sampah di RW 01 dan RW 02

\begin{tabular}{|l|l|c|}
\hline No & \multicolumn{1}{|c|}{ Jenis sampah } & Komposisi $(\%)$ \\
\hline 1. & Organik & 65,55 \\
\hline 2. & Kertas & 10,57 \\
\hline 3. & Plastik & 13,25 \\
\hline 4. & Kayu & 0,07 \\
\hline 5. & Kain & 0,61 \\
\hline 6. & Logam & 1,06 \\
\hline 7. & Kaca & 1,91 \\
\hline 8. & Sampah B3 & 1,52 \\
\hline 9. & Sampah Bongkaran & 0,81 \\
\hline 10. & Lain-lain & 4,65 \\
\hline
\end{tabular}

Sumber: Program PIL KAB, 2007

\section{2. Profil RT 08 RW 01}

Di dalam wilayah RW 01, terletak salah satu RT, yaitu RT 08 yang perlu mendapatkan perhatian khusus. Di RT 08 tersebut, kegiatan PSBM nya sudah cukup baik, sehingga dapat menjadi contoh bagi RT-RT di sekitarnya. Luas areal RT 08 sekitar $9.350 \mathrm{~m}^{2}$, terletak di Jalan Rawasari Barat VII. Di sebelah barat berbatasan dengan Jalan Rawasari Barat, sebelah utara berbatasan dengan RT 09, sebelah timur dengan Jalan Rawasari Timur dan sebelah selatan dengan RT 06. Jumlah penduduknya sekitar 160 jiwa atau $40 \mathrm{KK}$ dengan mata pencaharian utama pegawai pemerintah dan swasta.

Jalan Rawasari Barat VII merupakan jalan dengan lebar sekitar 1,5 meter. Sepanjang jalan tersebut kondisinya cukup hijau oleh tanaman hias dan bersih.

Program pengelolaan lingkungan hidup di RT 08 dimulai oleh ibu-ibu yang tergabung dalam program dasa wisma sejak 
tahun 2004 melalui kegiatan penghijauan lingkungan. Penghijauan yang dilakukan oleh ibu-ibu tersebut berjalan cukup baik sehingga lingkungan yang tadinya gersang menjadi sejuk. Oleh karena itu, pada tahun 2005 menjadi juara 2 Lomba Penghijauan tingkat DKI Jakarta.

Warga RT 08 mulai melakukan kegiatan kebersihan berupa pengomposan dan daur ulang sampah plastik setelah berhasil dalam program penghijauannya. Berkat kerja keras dan kepedulian mereka terhadap lingkungan, maka pada tahun 2006 kegiatan penghijauan dan pengelolaan kebersihannya mendapatkan perhargaan dalam lomba "Green and Clean 2006" yang diadakan oleh Yayasan Uli Peduli. Dari lomba tersebut, RT 08 mendapatkan hadiah sebesar Rp. 10 juta yang kemudian digunakan untuk program penghijauan dan pengadaan komposter.

Dalam program JBIC, RT 08 mendapatkan bantuan komposter sebanyak 6 buah dan peningkatan keterampilan kader lingkungan dalam rangka mendukung peningkatan kegiatan daur ulang sampah.

Sampai saat ini kegiatan penghijauan dan pengelolaan sampah masih berjalan baik sehingga memicu RT-RT tetangganya untuk mengikuti jejaknya. Bahkan kegiatan pembuatan kerajinan tangan berbahan baku plastik semakin meningkat dengan adanya pelatihan khusus dan bantuan mesin jahit dari Yayasan Uli Peduli. Kerajinan tangan tersebut berupa tas, dompet, tempat tissue, taplak meja, dsb. Di RT 08 terdapat sekitar 12 kader lingkungan yang dilatih oleh JBIC dan Yayasan Uli Peduli.

Baik kegiatan penghijauan maupun daur ulang sampah dilakukan secara swadaya. Pembiayaan kegiatan tersebut diperoleh dari iuran sebesar RP. 6.000 per bulan per KK yang dibayarkan pada saat arisan rutin bulanan. Uang iuran tersebut kemudian juga digunakan untuk keamanan, kegiatan sosial, dll. Setiap bulannya RT 08 membayar iuran sampah dan keamanan kepada RW 01 sebesar Rp. 90.000.

\subsection{Sistem Pengumpulan Dan Pengangkutan Sampah Ke TPS}

Wadah sampah yang digunakan oleh warga untuk membuang sampahnya sehari-hari cukup beragam seperti tong plastik, drum seng, bak yang disemen, ember plastik, dan kantong plastik. Namun, Sebagian besar wadah sampah yang dipakai $(50,6 \%)$ berupa drum dan tong plastik. Hal itu dikarenakan tong maupun drum gampang dipindah-pindah dan tidak permanen sesuai dengan lingkungan jalan yang sebagian besar berupa gang yang tidak terlalu lebar dan tanpa trotoar.

Sampah yang telah berada di wadah

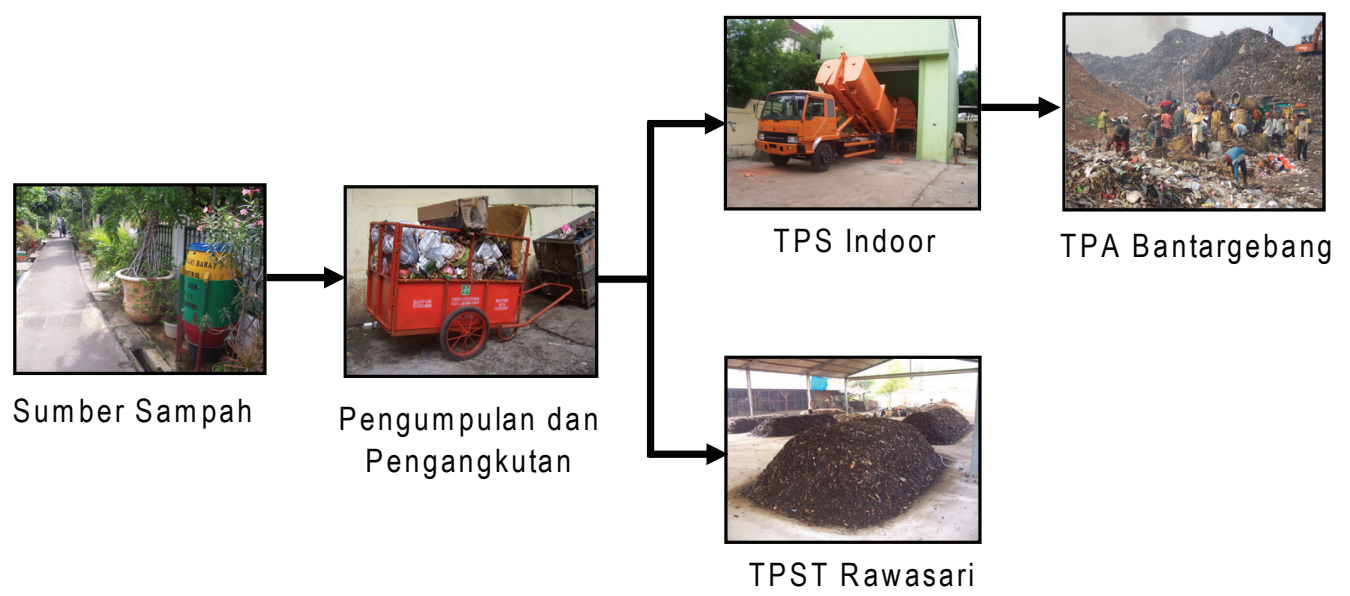

Gambar 2. Sistem Pengumpulan dan Pengangkutan Sampah di RW 01 dan RW 02 
sampah kemudian dimasukkan dan dikumpulkan ke dalam gerobak sampah oleh petugas penarik gerobak. Jumlah penarik gerobak di RW 01 ada 2 orang sedangkan di RW' 02 ada 4 orang. Sementara itu jumlah gerobaknya di kedua RW tersebut sebanyak 10 buah. Pengangkutan sampah dilakukan 2-3 hari sekali antara jam 07.00-11.00.

Saat ini, sebagian besar sampah yang tidak diolah sendiri oleh warga RW 01 dan 02 dibawa ke kompleks TPST Rawasari. Di TPST tersebut, sebagian sampah dikomposkan dan didaur ulang, dan sebagian lainnya dimasukkan ke TPS indoor untuk dipres dan diangkut ke TPA Bantargebang. Sebagian kecil residu sampah dibakar di dalam incinerator kecil (Gambar 2).

\subsection{Persepsi Masyarakat RW 01 Dan RW 02 Tentang Sampah}

Berdasarkan 38 buah kuesioner yang disebarkan terhadap warga RW 01 dan RW 02, masalah yang dirasakan paling mengganggu adalah masalah sampah $(42,1 \%)$ disusul dengan masalah air bersih $(39,5 \%)$ dan ruang terbuka hijau untuk bermain $(26,3 \%)$. Menyadari akan pentingnya pengelolaan sampah, maka warga kedua RW tersebut saat ini telah menjadikan pengelolaan sampah sebagai salah satu prioritas kegiatannya.

Menurut sebagian besar warga $(65,8 \%)$ yang paling bertanggung jawab terhadap pengelolaan sampahnya adalah pemerintah dan masyarakat, jadi bukan semata-mata masalah pemerintah. Oleh karena itu pengelolaan sampah di rumah juga dirasakan sebagai kewajiban setiap warga.

Jika sampah tidak terkelola dengan baik, menurut warga, maka akan menimbulkan masalah bau $(60,5 \%)$, saluran air tersumbat dan menyebabkan banjir $(34,2 \%)$, tempat berkembangbiaknya lalat $(39,5 \%)$ dan lingkungan menjadi jorok (34,2\%). Mereka $(79,1 \%)$ merasa sangat terganggu apabila sampah menumpuk di rumah.
Pengumpulan sampah yang dilakukan oleh petugas, menurut warga $(31,6 \%)$ bukan merupakan jaminan bersih. Namun sebagian besar warga $(89,5 \%)$ merasakan lingkungannya sudah cukup bersih.

Sebagian besar warga $(81,6 \%)$ mengusulkan daur ulang dan pengomposan sebagai upaya pemecahan masalah sampah. Sisanya menyarankan agar sampah dibakar atau dibuang saja.

Untuk melakukan pemilahan dan pengomposan sampah di rumahnya masingmasing, $71,1 \%$ warga menyatakan bersedia, $5,3 \%$ tidak bersedia, dan lainnya abstain. Sedangkan untuk upaya menjaga kebersihan got dan jalan, mereka $(60,5 \%)$ menyarankan untuk kerja bakti. Kerja bakti masih mudah dilakukan karena menurut warga (84,3\%) hubungan antar tetangga masih cukup baik walaupun berada di lingkungan perkotaan yang padat penduduknya.

\subsection{Kegiatan Pengomposan Di RW 01}

Para kader lingkungan telah melakukan pengelolaan sampahnya secara mandiri. Mereka telah secara rutin memilah-milah sampahnya untuk dikomposkan dan digunaulang atau didaurulang.

Pengomposan sampah dilakukan oleh seluruh kader lingkungan. Sebanyak $52,65 \%$ kader lingkungan telah melakukan pemilahan dan pengomposan sampah setiap hari, sedangkan yang lain melakukannya 2-3 hari sekali. Sebanyak $88,9 \%$ kader lingkungan yang tidak mengomposkan setiap hari beralasan karena jumlah sampah organiknya sedikit. Sedangkan lainnya (sebanyak $11,1 \%$ ) beralasan sibuk.

Jumlah sampah organik yang dimasukkan ke dalam komposter setiap kali pengomposan berkisar antara 100-1000 gram per keluarga. Sebanyak 47,4\% kader lingkungan mengomposkan sampahnya sebanyak 100-200 gram, 36,8\% kader sebanyak 200-500 gram, dan15,8\% kader sebanyak 500-1000 gram. 
Sampah organik yang dikomposkan antara lain berupa daun-daun pohon, sampah tanaman hias, kulit buah, sisa potongan sayur sebelum dimasak, dan sisa makanan. Jenis sampah yang dominan dikomposkan berupa sampah daun, kulit buah dan potongan sayuran.

Bagi sebagian besar kader lingkungan, teknik pengomposan yang diperkenalkan pada saat pelatihan (dilaksanakan oleh JBIC bekerjasama dengan BPPT) termasuk dalam kategori "mudah". Bahkan $21,1 \%$ sisanya menyatakan "sangat mudah". Dari praktek pengomposan yang dilakukan, mereka menyatakan bahwa proses pengomposannya relatif tidak menimbulkan bau, tidak muncul belatung, dan tidak diganggu oleh semut dan binatang pengerat lainnya. Teknik pengomposan yang diperkenalkan adalah hasil kajian Pusat Teknologi LingkunganBPPT.

Sampai saat ini kegiatan pengomposan masih tetap berlangsung.Jika komposter yang dipakai telah penuh, para kader akan mempersiapkan komposter lainnya untuk melanjutkan siklus pengomposan. Kualitas kompos yang dihasilkan cukup baik. Hasil tersebut sesuai dengan kualitas kompos hasil penelitian menggunakan komposter sejenis yang dilakukan di TPST Rawasari8). Kualitas kompos ditentukan berdasarkan parameter kompos matang 9,10,11 dan 12).

Komposter yang dibagikan masih terjaga dalam kondisi baik, bahkan mereka kadang-kadang menambahkan tulisan pada komposter seperti nomor RT dan RW agar kalau hilang dapat dilacak keberadaannya. Komposter sebagian besar diletakkan di depan halaman rumah, di pinggir gang. Komposter diikat kuat ke pagar agar tidak mudah dicuri orang.

Jumlah keluarga yang berpartisipasi dalam kegiatan pengomposan meningkat setelah diadakan pelatihan. Sebelumnya, (Agustus-September 2007), jumlah keluarga yang mengomposkan sampah di RW 01 hanya 26 keluarga. Akan tetapi sejalan dengan kegiatan monitoring dan sosialisasi oleh kader lingkungan jumlah keluarga yang melakukan kegiatan pengomposan terus bertambah hingga 41 keluarga pada bulan Januari 2008.

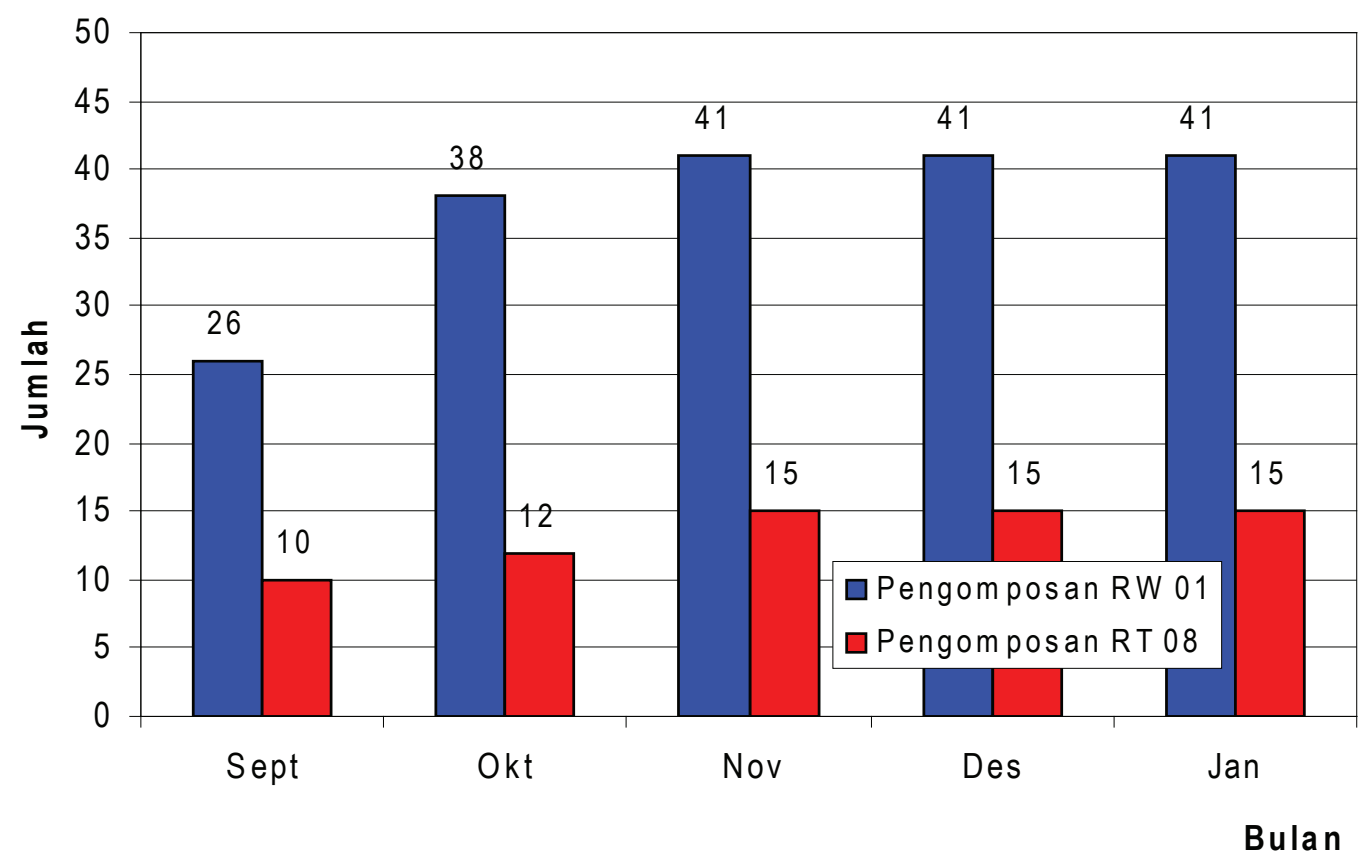

Gambar 3. Pemngoposan di RW 08 dan RW 01 


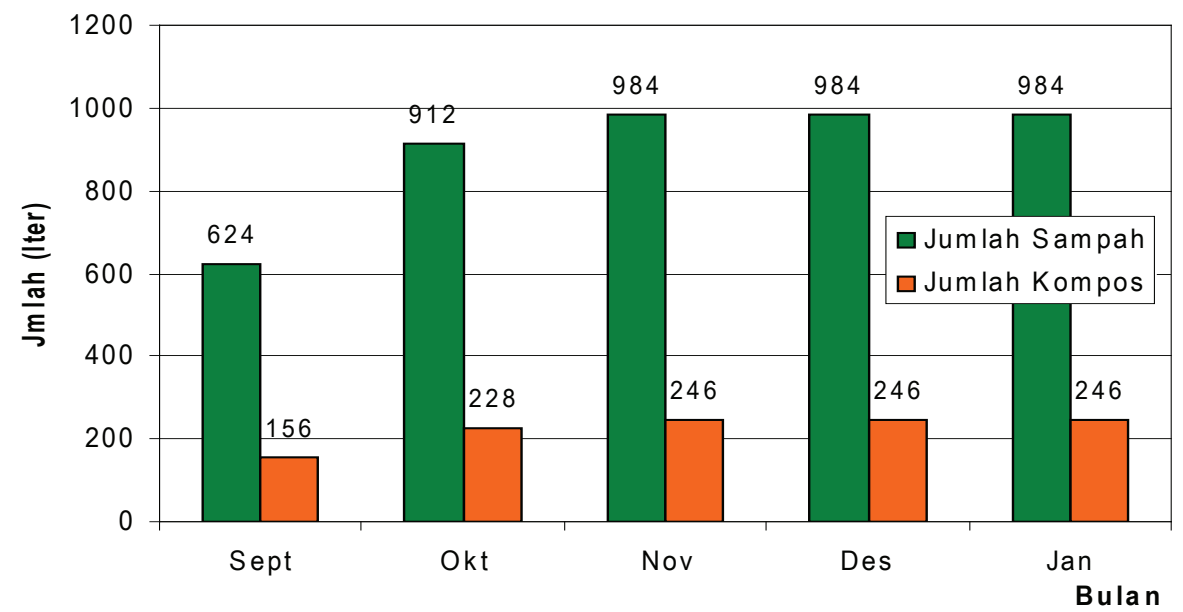

Gambar 4. Jumlah Sampah Dikomposkan dan Produk Komposannya di RW 01

Di RT 08, jumlah keluarga yang melakukan kegiatan pengomposan juga terus meningkat dari 10 keluarga pada bulan September 2007 menjadi 12 (Oktober 2007) dan meingkat lagi menjadi 15 keluarga (November 2007).

Jika dilihat dari jumlah sampah yang dikomposkan, maka jumlah jumlah sampah yang dikomposkan di RW 01 juga semakin meningkat. Pada saat sebelum pilot pelatihan, sampah yang dikomposkan diperkirakan hanya 624 liter per bulan, tetapi setelah pelatihan, sampah yang dikomposkan menjadi 984 liter per bulan. Sejalan dengan peningkatan jumlah pengomposan, jumlah produk kompos juga diperkirakan meningkat dari 156 liter menjadi 246 liter perbulannya.

Sementara itu, kegiatan pengomposan juga mulai dilakukan oleh 8 kader lingkungan yang dibina oleh JBIC di RW 02.

Diharapkan, melalui sosialisasi pengomposan dan daur ulang sampah yang dilakukan oleh para kader lingkungan, kegiatan tersebut semakin meningkat lagi.

\subsection{Daur Ulang Sampah Anorganik}

Pengelolaan sampah anorganik juga tidak kalah pentingnya dengan pengomposan. Sebanyak 42,1\% kader lingkungan menyatakan telah memanfaatkannya kembali sampah plastik antara lain untuk pot dan kerajinan tangan. Sedangkan sebanyak $21,1 \%$ mengumpulkan dan memberikannya kepada pemulung. Namun ternyata masih ada kader lingkungan (sebanyak 10,5\%) yang belum memanfaatkannya dan sampah anorganiknya langsung dibuang ke tempat sampah sebagaimana residu sampah lainnya.

Para kader lingkungan yang tersebar di masing-masing RT berencana akan mengkoordinasikan pengumpulan sampah anorganik yang bernilai tinggi dan selanjutnya akan didaur ulang atau dijual langsung sehingga dapat menambah penghasilan mereka. Seluruh kader lingkungan setuju jika uang yang didapatnya digunakan untuk kas RT untuk keperluan sosial.

Sampah anorganik plastik yang dijadikan pot umumnya adalah botol/gelas air mineral dan kaleng plastik cat. Sedangkan sampah plastik yang biasanya dibuat kerajinan adalah plastik-plastik kemasan yang tebal dan berpenampilan bagus.

Salah seorang kader lingkungan, Bapak Hendrik (RT 08/RW 02), telah memanfaatkan secara khusus kaleng plastik cat untuk bahan baku komposter yang dipesan oleh Yayasan Uli Peduli untuk disebarkan di berbagai tempat di Jakarta. Kaleng cat tersebut didesain sedemikian rupa dan 
dicat warna-warni sehingga penampilannya menarik.

Sementara itu, kader lingkungan Ibu Tri Darmayanti (RT 08/RW 02), telah mendapatkan bantuan mesin jahit dan pelatihan khusus pembuatan kerajinan tangan berbahan baku plastik kemasan dari Yayasan Uli Peduli. Produk kerajinan tersebut berupa tas, dompet, tempat tissue, taplak meja, karpet, dsb.

Saat ini sampah plastik kemasan dari produk Unilever seperti Molto dan Rinso, tidak dibuang lagi tetapi dikumpulkan untuk bahan baku kerajinan plastik. Untuk pemenuhan bahan baku tersebut, bahkan Ibu Tri sanggup membelinya Rp. 2.000 perkilogramnya karena masih kekurangan bahan baku. Produk-produk kerajinan tersebut nantinya akan ditampung untuk dijual di beberapa pusat-pusat pertokoan di Jakarta.

Keterampilan yang didapatkan oleh Ibu Tri saat ini telah dan sedang ditularkan kepada para tetangganya melalui berbagai pertemuan, seperti arisan. Ibu Tri bertanggung jawab untuk membina 5 kader lingkungan untuk dididik dalam pembuatan kerajinan plastik.

\subsection{Kegiatan Sosialisasi Daur Ulang Sampah Oleh Para Kader Lingkungan}

Kader lingkungan diberikan tanggung jawab untuk mengajak tetangganya agar menjaga kualitas lingkungan hidup di sekitar rumah masing-masing terutama yang berkaitan dengan masalah kebersihan dan daur ulang sampah. Para kader lingkungan juga mempunyai kewajiban untuk memberikan pengetahuan dan keterampilan pengolahan sampahnya kepada yang membutuhkan.

Melalui kegiatan pemilahan sampah dan pengomposan yang mereka praktekkan, seluruh kader lingkungan $(100 \%)$ menyatakan bahwa tetangga sekitarnya tertarik untuk melakukan hal serupa. Sebanyak $78,9 \%$ kader menyatakan bahwa tetangga mereka tertarik melakukan pengomposan karena sampah yang tadinya bau dan tidak bermanfaat dapat menghasilkan pupuk kompos. Selain itu, mereka tertarik mengomposkan sampah karena dengan melakukannya berarti turut berpartisipasi dalam program 3R $(57,9 \%)$ dan dapat mengurangi jumlah sampah sehingga ongkos transportasi sampah dapat ditekan dan umur TPA menjadi semakin panjang $(68,4 \%)$.

Transfer keterampilan pemilahan dan pengomposan sampah kepada tetangga sekitarnya telah dilakukan oleh sebagian besar kader lingkungan (89,5\%) sedangkan sisanya belum aktif melakukannya karena kesibukan pekerjaan pokoknya. Transfer ilmu dan keterampilan tersebut telah dilakukan oleh masing-masing kader kepada lebih dari 40 orang. Sebagian tetangga telah mereplikasi kegiatan pengomposan dengan komposter yang dibuat sendiri dari drum plastik $(57,9 \%)$ dan ember cat $(47,4 \%)$.

\section{KESIMPULAN}

Berdasarkan hasil penelitian dan pembahasan, dapat ditarik beberapa kesimpulan sebagai berikut:

1. Kegiatan PSBM di Rawasari berjalan dengan baik, terutama di RT 08/RW01. Motor penggerak kegiatan tersebut terutama ibu-ibu yang tergabung dalam program dasa wisma dan PKK.

2. Dengan pembinaan yang baik dan berkesinambungan telah meningkatkan aktivitas PSBM di Rawasari. Hal ini tergambar dari peningkatan jumlah keluarga yang berpartisipasi dalam kegiatan pengomposan, jumlah sampah yang dikomposkan, jumlah produk kompos, serta kegiatan pemanfaatan sampah anorganik menjadi produk kerajinan tangan

3. Aktivitas para kader lingkungan dalam mengajak para tetangganya untuk menjaga kualitas lingkungan hidup di sekitar rumah masing-masing 
(terutama masalah kebersihan dan daur ulang sampah) serta memberikan pengetahuan dan keterampilan pengolahan sampah kepada yang membutuhkan, telah mempercepat laju kegiatan PSBM di Rawasari.

4. Keberhasilan kegiatan PSBM di RT 08 pada khususnya dan di RW 01 pada umumnya tidak terlepas dari kerjasama yang baik antar berbagai stakeholders, baik yang berasal dari pemerintah setempat, instansi kebersihan, lembaga penelitian, LSM, lembaga asing, dan warga setempat.

5. Kegiatan sosialisasi keberhasilan PSBM di RW 01 dan RW 02 melalui kegiatan pencanangan gerakan PSBM yang dihadiri oleh Gubernur DKI Jakarta telah memberikan perasaan kebanggaan mendalam kepada warga sesuai dengan jerih payahnya selama ini dalam melakukan pengelolaan sampahnya secara mandiri.

6. Pemerintah DKI Jakarta saat ini menyadari bahwa melibatkan peran serta masyarakat, sangatlah efektif dalam menekan jumlah sampah sehingga biaya pengelolaan sampah menjadi efisien. Oleh karena itu kegiatan PSBM sekarang ini juga menjadi perhatian utama pemerintah DKI Jakarta.

\section{DAFTAR PUSTAKA}

1. Kelompok Kerja Air Minum dan Penyehatan Lingkungan, 2009. Keterlibatan Masyarakat dalam Pengelolaan Sampah: Suatu Keniscayaan. Laporan Utama Majalah Percik Bulan Mei, Edisi Khusus Pengelolaan Sampah Berbasis Masyarakat.

2. Sidik, U.S. 2009. Implementasi Peran Masyarakat Sesuai UU NO. 18 Tahun 2008. Majalah Percik Bulan Mei, Edisi Khusus Pengelolaan Sampah Berbasis Masyarakat, Pokja AMPL, Jakarta.
3. Yuwono, R, L. Wardhani, U. Ninghadiyati, dan E. Adinugroho, 2008. Pengembangan Sistem Persampahan Berbasis Masyarakat. Pokja AMPL, Jakarta.

4. Pusat Teknologi Lingkungan, 2008. Pengelolaan Sampah di TPST Rawasari. Kerjasama Antara Pusat Teknologi Lingkungan-BPPT dengan Dinas Kebersihan DKI Jakarta.

5. Dinas Kebersihan DKI Jakarta, 2007. Laporan Program PIL KAB di Kelurahan Cempaka Putih Timur.

6. Dinas Kebersihan DKI Jakarta, 2005. Laporan Akhir Solid Waste Management for DKI Jakarta, Master Plant Review and Program Development WJEMP Loan 4612-INO/Credit 3519-IND (DKI 3-11).

7. Kementerian Negara Lingkungan Hidup, 2008. Statistik Persampahan Indonesia Tahun 2008

8. Sahwan, F.L., R. Irawati dan F. Suryanto, 2004. Efektivitas Pengkomposan Sampah Kota dengan Menggunakan "Komposter" Skala Rumah Tangga. Jurnal Teknologi Lingkungan, Pusat Teknologi Lingkungan-BPPT, 5(2): 134139.

9. Tchobanouglous, G., H. Theisen and S. Vigil, 1993. Integrated Solid Waste Management, Engineering Principles and Management Issues. Mc Graw-Hill Inc., USA.

10. Epstein, E., 1997. The Science of Composting. Technomic Publishing Company Inc., USA.

11. Wahyono, S., F.L. Sahwan dan F. Suryanto, 2003. Menyulap Sampah Menjadi Kompos. Pusat Pengkajian dan Penerapan Teknologi Lingkungan BPPT, Jakarta.

12. Wahyono, S., F.L. Sahwan dan F. Suryanto, 2011. Membuat Pupuk Organik Granul dari Aneka Limbah. PT Agro Media Pustaka, Jakarta. 